This item was submitted to Loughborough's Research Repository by the author.

Items in Figshare are protected by copyright, with all rights reserved, unless otherwise indicated.

\title{
Organizing space and time through relational human-animal boundary work: exclusion, invitation and disturbance
}

\section{PLEASE CITE THE PUBLISHED VERSION}

https://dx.doi.org/10.1177/1350508416629449

\section{PUBLISHER}

Sage

VERSION

AM (Accepted Manuscript)

\section{PUBLISHER STATEMENT}

This work is made available according to the conditions of the Creative Commons Attribution-NonCommercialNoDerivatives 4.0 International (CC BY-NC-ND 4.0) licence. Full details of this licence are available at: https://creativecommons.org/licenses/by-nc-nd/4.0/

\section{LICENCE}

CC BY-NC-ND 4.0

\section{REPOSITORY RECORD}

Sage, Dan, Lise Justesen, Andrew Dainty, K. Trygesstad, and Jan Mouritsen. 2016. "Organizing Space and Time Through Relational Human-animal Boundary Work: Exclusion, Invitation and Disturbance". Loughborough University. https://hdl.handle.net/2134/20294. 


\title{
Organizing space and time through relational human-animal boundary work:
}

\author{
Exclusion, Invitation and Disturbance
}

\section{Abstract}

In this paper we examine the role that animals play within human organizational boundary work. In so doing, we challenge the latent anthropocentricism in many, if not most, theories of organization that locate animal agencies outside the boundary work that is said to constitute organizing. In developing this argument we draw together diverse strands of work mobilizing Actor-Network Theory that engage the entanglement of human/nonhuman agencies. In bringing this work together we suggest humans may organize, even manage, by conducting relational boundary work with animal agencies, spacings and timings. Our argument is empirically illustrated and theoretically developed across two cases of the spacings and timings of construction project organizations - an infrastructure project in the UK and a housing development in Scandinavia. Construction projects are well-known for their tightly managed linear timings and for producing the built spaces that separate humans and animals. Three concepts - Invitation, Exclusion and Disturbance - are offered to help apprehend how such organizings of space and time are themselves dependent upon entanglements between human and animal agencies. We conclude by suggesting that animals should not be negatively constituted as an 'Other' to human organizing, or indeed management, but rather acknowledged as sometimes constituting human capacities to organize, even managerially control, space and time. 


\section{Introduction}

Unruly individuals (Parker, 2014), technologies (Winiecki, 2009) and their attendant spacings and timings (Fleming and Spicer, 2004; Quattrone and Hooper, 2005) are readily shown to be effaced (Cederström and Fleming, 2012), removed (Clegg et al. 2006: 17; Parker, 2014) or discarded by human managers. Such troublesome actors, and their spacings and timings, thus appear to be both a target and limit for managerial domestication. Accordingly, in order to better understand the significance of boundary work in human organizing, and especially management, seems to require us to confront situations where 'wild' actors object to their domestication. Thus it might be expected that animals - the archetypical target, and perhaps also limit, of human domestication - present an exemplary opportunity to study the significance of boundaries in human organizing. However, this task is not unproblematic. Beyond organization studies, animals are frequently presented as being controlled by and for management: underweight, and unproductive, salmon are destroyed in fish farms (Law and Lien, 2013); mating, and obscene, chimpanzees removed from public view in zoos (Grazian, 2012); infective bacteria cleaned from poultry sheds (Miele, 2011); uncooperative cows taken from the automatically milked herd (Holloway, 2007) and younger, more profitable, alligators sifted into skin farms (Keul, 2013). These studies thus offer compelling stories of domestication where animals become controlled by managers to serve, or not serve, organizational ends, entering into or out of preformed organizational spaces and times.

The problem is that if animals only appear as significant in relation to human organizing as passive 'objects' that comply, or not, with their managed domestication, it is difficult to understand the multiple ways their 'wildness' makes a difference to, rather than is placed 
outside, human organizing. This is the starting point for our analysis: to challenge the boundary work that currently places animals outside of processes of organization. By drawing on Actor-Network Theory (ANT) (Latour, 2005) we explore somewhat paradoxical possibilities that human organizational boundary work, even that which appears to exclude animals from human organizing, can be conceptualized as the relational outcome of complex entanglements between human-animal agencies, spacings and timings. Thus the aim of our paper is to problematize the urge towards domestication that places animals outside human processes of organizing, and indeed management. As such we also aim to contribute towards wider debates that discuss the role of 'wild', disorganizing agencies, spacings and timings, alongside the boundary work constitutive of human processes of organizing, and in particular those of management (Bloomfield and Vurdubakis, 1999; Clegg et al. 2005; Clegg et al. 2006; Knox et al. 2015).

This argument for (re)thinking organization with animals brings together different strands of thinking in and around ANT on: relational approaches to organization (Latour, 2013); animal geographies (Bear and Elden, 2011; Holloway, 2007; Philo and Wilbert, 2000); heterogeneous agencies (Callon, 1986; Latour, 2004; 2005; Law and Mol, 2008) and relational spacings and timings (Latour, 1986; Law, 2002a). Our argument is worked through two illustrative empirical cases of human-animal organizing in the construction industry. Construction is not unique in contributing novel insights into the significance of animals within human organizational life, but the managed production of the built environment presents us with a set of organizing practices that are visibly involved in producing separate human and animal spaces and times (Philo and Wilbert, 2000). It thus offers an important setting to investigate relations between human-animal boundary work. 
The paper is arranged into three sections. First, we critically examine the boundary work that locates animals outside of human organizing. Then, secondly, in order to investigate animals as potentially making a difference to such acts we turn to relational approaches to organization influenced by various ANT studies, and animal geographies, to recognize that animal actors can be involved in organizing. Analytically this involves a triad of concepts Invitation Exclusion and Disturbance - which carry to the fore particular practices of relational boundary work between humans and animals. These boundary concepts are understood relationally, drawing attention to how capacities for humans to invite, exclude, disturb animals, are entangled with capacities for animals to invite, exclude, and disturb humans. Thirdly, we draw upon two empirical studies of construction projects to illustrate how animals make a difference to organizing and management. Drawing on Invitation Exclusion and Disturbance this investigation provides insights into the ways in which organizational, and management, boundary work can be enacted with and through, rather than simply against and beyond, animal agencies, spacings and timings.

\section{Organizing and Boundary Work}

Organizational theories tend to locate animals outside the boundaries of organizing in two principle ways. The first approach, which we term 'managerialist', draws from organizational theories such as transaction cost economics, resource-based views of firms, systems theories and other related approaches (Santos and Eisenhardt, 2005; Schreyögg and Sydow, 2010). In their well-cited review of organizational boundaries Santos and Eisenhardt (2005) explain that for organizations to survive and thrive, a select group of human managers must do boundary work, via control techniques, to delineate an organization's efficiency, power, 
competency and identity in a volatile global market environment. Within such accounts ‘environment’ quickly becomes a synonym for 'business environment’ (Klikauer, 2013: 207), just as ‘organizing' equates to 'management' (Parker, 2002: 200). Such approaches are said to rehearse a teleology whereby 'management is a precondition for an organized society' and 'social progress is equivalent to our ability as human beings to increasingly control the nature worlds around us' such that 'Where we were once the victims of a wild, unruly nature, we are now becoming masters’ (Parker, 2002: 2-3; cf. Klikauer, 2013: 41). This managerialist discourse denies nonhuman agencies - including animals - a role in organizing unless they passively serve as a marketable resource for market managerial ends, as in 'green' accountancy (Milne and Gray, 2013) and planetary geo-engineering (Anderson, 2014). Thus 'management' is to be defined not only as the naturalization of elitist hierarchies, generalized techniques of control, or the primacy of maximizing shareholder value, but also the commodification of 'Nature' (Klikauer, 2013; Newton, 2009; Parker, 2002) - the exclusion of animals from acts of organizing.

A parallel approach to the evisceration of animals from organizing can be found in some poststructuralist accounts, especially those influenced by Cooper's Organization/Disorganization (1986). As Cooper (1986) explains, drawing on Derridian deconstruction, 'In its most fundamental sense, organization is the appropriation of order out of disorder' and so 'social structures are ordered, organized and made decidable always at the boundary line between opposing forces, between inside and outside, good and bad' (p327). For Cooper (1986) the ordering and decidability within organizations is thus defined through a process of 'Othering' where monstrous excesses of disorder and undecidability are purged: 'The struggle for the "superior" position necessarily requires the "support” of an "inferior" positions inasmuch as the latter is what defines the former" (p328); it is that 'the purging of 
“bad” which threatens the system’s internal purity and security' (p327). Unruly and wild agencies, including animals, are thus prefigured as productive negations that define organization in terms of order, decidability and control (Clegg et al. 2005: 152-3). Inspired by Cooper (1986), Bloomfield and Vurdubakis (1999) for instance, discuss, how the UK’s Ministry of Deference sought to 'Other' the monstrous, disorganizing, agency of the possibility of a big cat killing sheep on Bodmin Moor. These, and other organizational scholars (e.g. Riach and Kelly, 2015; Thanem, 2006), have shown how organizing is enacted through boundary work that involves the negation of monstrous, disorganizing 'Others'. No matter how much we might celebrate the radical disruptiveness of monsters to disorganize (as in Riach and Kelly, 2015; Thanem, 2006), 'monsters', including animal agencies, are inevitably reproduced in such accounts beyond the boundaries of socially valued ways of organizing and talking about organizations.

A rather different take on the significance of boundaries to processes of organizing and therein the role of animals can be found in the work of Latour (2013). His work parallels some recent organizational theory (e.g. Clegg et al. 2005; Knox et al. 2015) in amalgamating notions of organization/disorganization: 'To organize is not, cannot be, the opposite of disorganizing. To organize is to pick up, along the way and on the fly, scripts with staggered outcomes that are going to disorganize others' (Latour, 2013: 393, emphasis in original). For Latour the significance of boundaries to organization does not concern generalized organization/disorganization distinctions, but rather the co-ordination of 'contradictory injunctions' (Latour, 2013: 396) that limit us spatially, temporally and agentially (Latour, 2013: 397), so as to effect 'something that has borders, frontiers, mandates, limits, walls, ends' (Latour, 2013: 398). This 'something' is a temporarily stable organization (e.g. a regular meeting, corporation, enduring empire). To negotiate these contradictory injunctions', 
and their actual and potential spatial, temporal and agential limitations, actors are said to perform spatial, temporal and agential boundary work that do, undo and transform the limitations and contradictions placed upon them and other actors (Latour, 2013). Boundaries are thus constituted relationally within not on the margins of acts of organizing, as actors spatially, temporally and agentially organize and disorganize themselves and others. Thus crucially for our purposes here, Latour also suggests that actors are themselves relational effects (Latour, 2005); as such, nonhumans, including animals, can be considered actors if they make a difference to these spatial, temporal and agential processes of organizing.

To be clear, Latour does not suggest that nonhumans, including animals, act sui generis to set boundaries on humans, that is, to dis/organize us; indeed Latour (2005) rejects the idea that agency is a distinctly human or nonhuman property. Rather, as per ANT, agency is relational, based on differences that recursively produce more differences; it is constituted by the interplay of 'different types of forces ... because they are different' (Latour, 2005: 75; original emphasis). ANT thus reverses any notion that agency is the basis of difference, say between humans and nonhumans (contra Collins and Yearly, 1992; Whittle and Spicer, 2008); instead the intermingling differing of difference produces agency. Viewed in this way, agency is disentangled from (human) intentionality (Law and Mol, 2008: 58): an actor can be anything that makes a difference to the situation at hand - a 'moment of indeterminacy that generates events and situations' (Law and Mol, 2008: 74; original emphasis). Agency, including that involved in the boundary work that constitutes organization (as described by Latour, 2013), thus is itself constituted through recursively transformative interactions between human and nonhuman actors. 
In short, ANT draws attention towards 'how places and entities are 'framed' by actions/agencies from elsewhere' (Hassard et al. 2008: 63). ANT’s relational approach to boundaries thus also demands that rather than 'space' and 'time' pre-existing their relations, focus is given on 'how different spaces and times may be produced inside the networks built to mobilise, cumulate and recombine the world' (Latour, 1986: 228). Elaborating on this point, Latour (1986: 230) offers the example of early European maritime expeditions: new ships connected European capitals to distant peoples, goods and lands, broadening spatial horizons, and creating new times that interrupted the routines of the past. Space-time is herein pleated and folded (Murdoch, 1998) because distant objects such as foreign coastlines or goods, circulate inside nearby stabilized networks, such as those formed between ships, states, water, stars, wind, compasses and various other navigational instruments (Law, 2002a; Latour, 1986). These extended, stabilized networks permit certain objects, such as ships or goods, to travel without deformation just as the extension of similarly stabilized networks allows scientists to act as spokespeople for certain 'universal facts' no matter when and where they travel (Callon, 1986; Latour, 1986). Viewed as such, the relational boundary work through which bounded actors and agencies are constituted, also delineates spacings and timings. Any particular, delimited, space-time thus becomes a product of drawing alignments between certain actors (see Jones et al. 2004; November et al., 2010). Despite important debates by ANT proponents on this subject, for example around the ontological primacy of networks as constitutive of space (compare e.g. Latour, 1986 and Law, 2002a), ANT suggest the importance of relations in constituting boundaries of agency, space and time. This is why Mol and Law (2005) suggest of ANT: 'the problematisation of boundedness does not mean the end of boundaries' (p641). However thus far this body of work has remained rather detached from theories of organizational boundary work (including that of Latour, 2013). To 
understand its significance to such debates we now turn towards ANT influenced animal geographies.

\section{Boundary work and animals}

ANT research has long inspired animal geographies, extending early ANT studies of relational ordering that included animals (e.g. Callon, 1986). These studies focus on the specific differences animals make to boundary work, they also offer points of reference to analyse how animals make a difference to organizing. Holloway (2007), for instance, examines how dairy cows interact with automated milking machines in complex ways, requiring spatial and temporal modifications and adjustments to the barn in order to promote successful milking (e.g. placing non-return gates between the automated milking machine and food and water, allowing lower ranked cows access to leave the milking barn if they are threatened by a higher ranked cow etc.). As he explains: 'technology and layout [of the barn] are affected by the cows' bodies and behaviours, and bodies and behaviours are affected by the technology and layout' (Holloway, 2007: 1051). Here animals are shown to make a difference to how humans, presumably farm managers, organize as they establish boundaries around the spacings, timings and agencies of cows to pursue (cost) efficiencies in dairy farming.

Other animal geographies help us understand how animals and humans might organize, that is, set agential, spatial and temporal limits (Latour, 2013), in more fluid ways (and more fluid space-times - see Law, 2002a) - for example Bear and Eden's (2011) study of angling. It 
shows how in their riverine interactions, anglers and fish exchange certain agential capabilities, as they adapt to, and to an extent modify each other's bodily rhythms, (rephrasing Deleuze and Guattari, 1987 - anglers ‘become-fish’ and fish ‘become-human’). For instance, they write how 'Their [the anglers] inability to see below the surface of the river ... is often balanced out by honing their other senses, such as touch (in feeling the shape of the riverbed by dragging a weight across on the end of a fishing line (Bear and Elden, 2011: 346); this practice is analogous to the barbles used by riverine fish in murky water to find their food. Bear and Elden (2011) also discuss how some fish avoid feeding in those times of the days most frequented by anglers. Thus the agencies, spacings and timings of humans and animals become entangled, but only in order to reinforce boundaries more forcibly: for humans to minimize the time spent between catches and for animals to render their more fluid space alien to humans and evade being caught. Instead of deriding anthropomorphisms, like Whittle and Spicer (2008), animal geographers readily propose a 'guarded anthropomorphism' (Philo and Wilbert, 2000: 20) as an ethical virtue to register our shared agency, spacings, and timings, our shared suffering and delight (Greenhough and Roe, 2011), while not downplaying relationally-given differences, detachments (Ginn, 2014) and boundaries (Bear and Eden, 2008).

Animal geographers propose various ways in which animal agencies inflect human processes of organizing. However, the boundary work they describe often appears somewhat domesticated inside a set of stabilised human organizations (e.g. farms, laboratories, supermarkets etc.) wherein spatial, temporal and agential boundaries are determined by human managers to pursue (cost) efficiency in the market (e.g. Greenhough and Roe, 2011; Holloway, 2007; Miele, 2011). Animals that refuse to accept their institutionalized domestication are then simply systematically removed by management (Holloway, 2007). 
Alternatively, when more fluid, uncertain, agential interactions between animals and humans are described these tend to be positioned against (Keul, 2013), or beyond (Bear and Elden, 2011; Ginn, 2014), the domain of management. Consequently the variety of ways animals might make a difference to how humans organize, and especially manage, remains neglected. The following empirical study is intended to provide a more symmetrical account that registers the different ways humans organize, even manage, with animals.

\section{Cases and methodology: Building Organizations with Animals}

Contemporary construction represents one of the most important, yet remarkably overlooked, places to study human/animal encounters (Sage et al. 2014). The construction industry is a major threat to animals and their habitats spanning a wide continuum from the temporary displacement of wildlife by noise and dust during to animal extinctions and the permanent destruction of entire ecosystems. The construction industry has also become a focus for innovative wildlife experiments, from small-scale urban conservation projects (Lorimer 2008) to green infrastructure megaprojects (Tajima, 2003).

Our two cases in infrastructure and house building help to illustrate the entanglement of animal and human boundary work rather than offer detailed, empirical case studies. While sharing a common project-based organizational form, and other similar organizational contexts (despite one being located in the UK and one in Scandinavia), the two cases illustrate different boundary work practices wherein animals, and their habitats, are involved in organizing. To help focus on relational boundary work, we delineate a set of analytical 
concepts which explain how boundaries keep actors apart, how boundaries foster new collective agencies, and how the dynamics of boundary work unfolds, in short: Exclusion, Invitation and Disturbance. Exclusion is the process whereby an actor is absented from a particular process of organizing. It can correspond to either the removal of actors outside a certain process of organizing, or their more absolute obliteration. Such boundary work can be spatial - actors occupy, and organize, in separate territories - or temporal - actors occupy, and organize, a space at different times. In contrast, Invitation is the process of strengthening relations between actors. This involves transforming their roles and potentials to act. Boundary work is herein concerned with new, or resurgent, forms of existence for all actors involved. The fate of one actor thus becomes tied to another (Callon, 1986), engendering collective destinies. Lastly, Disturbance refers to the ongoing re-negotiation of roles and boundaries. This is why, for ANT proponents, no stabilization between actors can be guaranteed (Latour, 1986). New actors may enter the organizing process, new interpretations may be given of events, tacit assumptions may turn out to be mistaken and surprises may happen. Actors, such as animals, become 'troublemakers' that 'emerge in surprising fashion, lengthening the list of beings that must be taken into account' (Latour, 2004: 79, emphasis added). Taken together these three theoretical concepts make it possible to understand boundary work as it happens relationally between human and animal agencies.

Our two cases were developed for different reasons and at different time periods. When we began our study of the Scandinavian case company (DEF) we did not focus particularly on human/animal organizing as our overall aim was to do an explorative, open-ended study of relations between projects and firms. In line with ANT concepts of agency, we were interested in who or what made a difference in the project, how such differences were made and with what consequences (Latour, 2005). This open approach allows surprises that, 
according to Latour (2013: 34), are unexpected elements arising from the empirical work that have to be added to the analysis. In an initial interview with a DEF project manager we asked him what he thought were the biggest challenges in the project. To our surprise, he said that one of the most difficult things to handle had been the unexpected presence of about 500 moor frogs at a particular construction site and the effect this has had on the project's construction schedule. This led us to focus on the question of temporal organization and animals as one aspect of the larger case study. It became clear to us that animals could be seen as challenging organizational boundaries and we decided to pursue this question of animals and organizational boundaries by exploring another case where we, in contrast to the Scandinavian case, knew in advance that the presence of animals was an issue. In that sense, the UK case, presented below, was a more planned exploration of this question with an explicit focus on animals and organizing in all interviews. The UK case was developed through an extant relationship with an infrastructure organization who provided us with access to data and people relating to a recently completed project where animals had become a concern. The two cases supplement each other by illustrating different aspects of how animals participate in organizing boundaries. Below we give more detail about the two cases and the empirical material that informs our analysis.

The Scandinavian case concerned a project owned by a developer company DEF (a pseudonym) that was one of the big players in the Scandinavian construction industry in terms of revenue and profit at that time. The interviewed manager referred to a site in the suburbs of the capital city purchased by DEF with the aim of developing, building and selling about 80 hectares of new residential houses as well as renovating some existing buildings at the site. The building activities began in 2004 and the fieldwork on which the case study is based was conducted in 2006 while the construction activities were still going on. Our study 
was based on 9 qualitative interviews (with DEF managers, employees and subcontractors), a week's field study on the construction site where we followed the DEF project manager during his workday, including site inspections, participating in meetings, etc. It also included many informal conversations with the project manager and other people working at the project. In addition we read numerous documents, including DEF annual reports, project plans, marketing material, consultant reports, documents from the local authorities, and newspaper articles. These documents played an important role in our reconstruction of the frog case because they could reach further in time and space than any individual could recount.

The case located in the UK concerns an infrastructure project: the construction of a $£ 45 \mathrm{~m}$ value, $1200 \mathrm{~mm}$ high pressure gas pipeline across $18.5 \mathrm{~km}$ from protected 'green belt' land into the outlying suburbs of a large conurbation. Construction took place between 2007 and 2010. The project client was a multi-national, privately-owned, regulated monopoly utility provider (named here 'Gasgen'). This project was unremarkable: it was not an environmental catastrophe and indeed received a sustainability award for waste management; however it did involve the unusual construction of a large gas pipeline through a 'green finger' of uninhabited land into a large conurbation. To understand how animals, and their habitats, interacted with the organization of this project, between 2012 and 2014 we interviewed those most concerned with responding to their unpredictable presence within the project: two environmental managers within the client environmental division; the client's project environmental officer; the general contractor's environmental officer; the client's project manager; a sub-contacted environmental consultant; two local authority wildlife officers; and three people working for local wildlife charities involved in managing local wildlife reserves. These individuals were asked in semi-structured interviews to, inter alia, describe how 
wildlife was managed on the project, how wildlife shaped the project's development, and whether the project was typical of their experience of infrastructure projects. After the interviews, and post-construction, we walked through the site with several of these individuals to situate their experiences of the project and its ecologies. These field interviews helped us glimpse some of the complex animal agencies involved in the project more directly. Despite the historical nature of the case, many of the traces of the complex interactions between animals and humans on the project remained physically evident (e.g. new wildlife spaces, abandoned protective fencing). This data was thematically coded alongside documentation including: the Environmental Statement, environmental 'best practice' case studies prepared by the client and contractor, minutes of planning minutes within the local authority and environmental mitigation protocols. As with the DEF case, across our heterogeneous dataset, thematic coding focussed upon tracing the different agencies that made a difference to the spacing and timing of the project.

For both cases, the empirical material was read and reread several times by all research team members in an open manner consistent with the agnostic and symmetrical approach of ANT where the agency of no actors is privileged in advance (e.g. Latour, 2005). As we conducted our analysis of both cases it became clear to us that the animals, and their habitats, could be seen as actors in the ANT sense of the term because they clearly made a difference to the organization of the projects in the question. On this basis, we read the material with the aim of tracing the different associations that these actors formed, how they were transformed and how they transformed each other, and how these agential relations affected the (human) organizing processes of the project. In that sense, our conceptual triad of Exclusion, Disturbance and Invitation were conceptualizations formed on the basis of a close reading of the material. Once formed, however, we reread the material from both cases with the aim of 
analyzing the relations between organizing, boundary work and animals. If we had started with other actors and associations, e.g. those forged by environmentalists or been able to follow the animal themselves as events unfolded, our case stories may have revealed different stories. However, in acknowledging these access limitations, which derive from the access granted by the construction firms involved, it is important to stress the specific purpose of our paper is to understand how animals make a difference to human organizing, and especially management. By focusing upon how human, mostly management actors, register these differences our empirical evidence is commensurate with this specific task. As our cases will disclose, from the point of the view of our participants, in the Gasgen project boundary work was primarily oriented towards the spacing of animals appeared as the primary concern to ensure the planned temporal organization of the project, whereas in the DEF case it was animal timings that become the principle concern to achieve the planned spatial organization

of the project. Thus while to a degree both cases demonstrate the significance of spatial and temporal organizing, they are mobilized here to separately illustrate and elaborate upon the significance of human/animal boundary work to spatial, and then temporal, organizing.

\section{Organizing with Animal Spacings}

\section{Exclusion}

Projects are typically bounded by their management of time, cost and quality. For animals, boundaries include temporal cycles of species, spatial boundaries of habitats and agential interactions between species and habitats that comprise ecosystems. In construction, spatial 
exclusions make it possible to separate these two ways of organizing, typically via physical fences, blockades and walls - mechanisms that prevent different agencies from disorganizing each other. But these processes of exclusion do not simply correspond to static boundaries between the 'inside' and 'outside' of organizations (Cooper, 1986; Santos and Eisenhardt, 2005), rather they are relational outcomes of boundary work.

In the UK Gasgen project the separation of project and animal organization was twofold, it involved: (i) the network stabilization of animals by project ecologists who could speak for them (Callon, 1986) and (ii) ad-hoc, or fluid, adaptations to animal agencies by the wider project team. Concerning stabilization, a series of practices were devised to exclude animals from project space including high wooden hoarding fences, the pruning of trees near to access tracks to prevent nesting birds from encroaching onto the site, the use of timber matting on access tracks to allow small animals to pass beneath, the placement of escape routes in pipeline trenches for stranded badgers, the availability of an ecologist to relocate animals found within the site boundaries, special vibrating tape hung between posts to scare away breeding birds from nesting within the site boundaries, temporary exclusion fencing around great crested newt ponds and the mowing of grass within the site boundaries in advance of construction to prevent the passage and nesting of reptiles (grass snakes, lizards, adders, slowworms). These technologies relied upon the support of expert spokespeople (ecological professionals) through which the organizing of animals and their habitats could circulate and be consistently articulated to project professionals (Callon, 1986). The strength of these circulatory articulations was themselves dependent upon alignments between a network of heterogeneous materials (Latour, 1986), including environmental impact assessment audits, wildlife laws, legal penalties, company policies, agreed budgets for environmental protection, project plans, along with certified qualifications, field experiments, 
laboratory experiments, and scientific papers. The circulation of animal agencies into project management was thus at least partly dependent upon a fragile network of practices of registering animal agencies elsewhere in time and space.

Other acts of exclusion were constituted by more emergent adaptations between humans and animals. For instance, in some areas, the lack of tall grass, and piles of bare earth, within the boundaries of the construction site attracted nesting skylarks despite bird scaring tape. This was met by ad-hoc bird scaring by sub-contractors and park rangers, notably the instalment of noisy diesel generators in prominent locations and regular ground patrols. The success of this ad-hoc measures required the project team to exchange agential qualities with animals in a quite fluid manner (Bear and Eden, 2011), to effectively think like animals - how can they move, what do they like, what do they dislike, even what does this bird seem to like/dislike, and what can their bodies do?

The effect of these exclusions made it possible to allow the construction team to proceed as if animal agencies, spacings and timings were excluded from their organizing. But crucially, these spatial exclusions did not simply involve the reduction, or domestication, of animal agency. Rather, whether across a stabilized network or within more ad-hoc adaptations, animal agencies were now registered and circulating within the organizing of project management - they made a difference - but they only made a difference in so far as to help further their own exclusion from project organizing. Human organization and animal organization were thus separated to ensure they do not disorganize each other. This separation was, of course, helped along by wildlife law, institutions and professionals that could stop construction had the animals been harmed. But the successful maintenance of 
these boundaries certainly relied on the enrolment, to a certain extent, of animal organizing inside the organization of project management, so that animal agencies became reliably positioned outside of construction activities. In other words, this paradoxical recursive entanglement and disentanglement of animal/human agencies, prevented conflict and allowed project management to continue on its predetermined plan.

Invitation

The success in maintaining separation between project management and animal organizational had its limits. Sometimes animal agencies were invited into project management and changed the direction of the project. For example, one invitation happened during negotiations to cross the River Ox, a small river located next to a major urban highway. Whilst most river crossings, and protected riverine animals on the project had been excluded from project management by placing pipelines in bored tunnels under river habitats, on the River Ox the project team proposed to offset time delays and budget overruns elsewhere by employing open-cut excavation. This technique involved damming the river, rerouting its flow via temporary pipes and pumps, digging a trench, laying the pipeline, and reinstating the river. Consent for this proposal was successfully granted by the statutory authority because Gasgen agreed to fund a specialist sub-contractor to undertake significant habitat enhancements on this section of the Ox. These enhancements included the removal of Himalayan balsam (an invasive plant that can overgrow river banks impeding native riverine plants and water vole habitats), the creation of a backwater waterhole as a habitat for fish, insects and amphibians, the instalment of flow deflectors, berms, gravel bars, and pebble 
riffles to increase the oxygen content of the water to nurture fish and provide egg laying areas; and the re-grading of the river bank to enable easier access by riverine animals.

This example of boundary work is not simple one of exclusion, of separation, wherein animals make no, or little, difference to the predetermined organization of a project; this is because in this instance the boundaries of the construction project also changed. That is, the shape of the pipeline changed: its three-dimensional boundaries were disorganized - the depth of pipeline was reduced, saving project management time and money. Project management thus became dependent upon the simultaneous disorganization and reorganization of project parameters along with animals' habitats. The decision to open-cut the river was certainly detrimental, in the short-term, to riverine animals - hence the original plan to recommend tunnel boring to avoid damage. However, this act helped secure the planned route of the project, as well as project deadlines, while also potentially at least producing spatially expanded habitats for riverine animals. In other words, this boundary work involved mediating between project management and animal organizing, project characteristics could only be changed if animal organizings were changed. Thus human and animal agencies are entangled not simply to police their separate organizings, rather the fate of their organizings becomes more profoundly tied to each other. What is more, this act of invitation cut both ways: animals were invited by humans to be tied to their organizing, just as humans were invited by animals to be tied to their organizing. Indeed, the very abundance of animal habitats in this area, and other areas along the pipeline route, invited the project into their habitats in the first place. This is because large diameter gas pipelines cannot, in the UK, be legally routed under buildings - the pipeline required their 'wild' space, just as animals may one day require the pipeline to protect themselves from urban sprawl. Such 
examples suggest how human and animal agencies become entangled in new ways, creating collective destinies.

\section{Disturbance}

Thus far the Gasgen example has served to explain two different ways through which animal organizing makes a difference to (human) project management. Importantly, these two forms of organizing and their particular, indeed different, delimitations of agency, space and time, were produced relationally through agential entanglements. We have proposed two concepts: exclusion and invitation to make sense of the different forms these entanglements might take. We would now like to propose a third: disturbance. These acts offer a different agential starting point to those analysed thus far; namely here we begin with animal organizing rather than project management, specifically a group of badgers. These badgers occupied a woodland sett discovered on the planned pipeline route. Natural England, the UK statutory body charged with enforcing wildlife legislation, stipulated that the badgers could not be harmed or removed from the sett as this would be illegal under the 1992 Badger Act; the project team were told to exclude the badgers from space by constructing an artificial sett outside the project boundaries and then using food to entice them to move into this sett. As with the discussion of exclusion above, the production of spatial boundaries by project management was contingent upon the extension of a stabilized network, through which the spokespeople for the badgers (Natural England) and their techniques of exclusion could travel into any place, at any time, essentially speaking for all badgers. 
Despite repeated efforts to extend their ecological network, alongside more fluid ad-hoc practices (experiments in food types and trails), the badgers organizing, their spatial and temporal boundary work, remained unassimilable to project management. The badgers decided not to incorporate the new sett into their territory, and, owing to the presence of nearby housing, no other route was legally possible. Here the badgers made a difference, they challenged their designated expert spokespeople (Natural England) by refusing the extension of Natural England's ecological network to speak for them, and their agency, into this woodland. But Natural England did not themselves lose interest in badgers, even if the badgers appeared disinterested in them. Instead Natural England, instructed by the 1992 Badger Act, reiterated their refusal to allow the project team to move the badgers, that is, to disrupt the badgers' boundary work. Consequently, the project team had to disorganize the pipeline. This involved boring a tunnel beneath the original badger sett, an event which added around $£ 500,000$ to the project costs and delayed it for several weeks; however, these costs and the delay was to an extent mitigated by the (previously unplanned) opportunity to open cut the River Ox later in the project.

In this example, the refusal by the badgers to be aligned with their spokespeople (Natural England), changed the spatial and temporal (and budgetary) limits of the project. In other words, they made a difference, they acted, but they did not possess agency. Rather their power to refuse, their agency, was relationally constituted: it was contingent upon their interactions with their presumed spokespersons from Natural England, along with the 1992 Badger Act and technological objects like an artificial badger sett. Here the transformative interplay between humans and animals, and other nonhuman objects, equips the badgers with 'their' agency to refuse (or not). But this refusal does not correspond to their exclusion from human organization or an invited conjoining with human organizing, rather their refusal 
disturbs, or disorganizes, human organizing in a less certain, asymmetrical, way. In the next section we turn to our second construction case to illustrate how these three aspects of boundary work - disturbance, exclusion, invitation - can also help to elucidate the different temporalities through which animals make a difference to project organizing. We start with another story of disturbance.

\section{Organizing with Animal Timings}

\section{Disturbance}

It came as a surprise, and at first an unwelcome one, to DEF when environmentalists made them aware that their construction site contained not only two, partly hidden ponds, but also about 500 moor frogs, a species protected by European Law (EC Directive 92/42). This discovery disorganized the project. Time, and in particular speed, was a very important aspect of DEF's business model (Tryggestad et al. 2013) as expressed in the following quote from an interview with DEF's CEO:

You know, we're really fast. That's one of our parameters. We've always been 3-6 months faster than our competitors [. . .] That's why we hardly ever buy a piece of land where we have to struggle with the plans for 5, 6 and 7 years. Normally, we will buy something that is easy to approach - with a district plan process that is almost 
settled. We want to finish the project in the same market because the market fluctuates. So the speed of a project is a very important parameter for us.

It was important to DEF's managers to organize their project within a linear chronology with strict deadlines. The frogs threatened to disorganize the temporal boundaries set up around the project and its timings. This project organized time into a set of linear slices, a critical path of tightly interlinked project tasks, defined around the beginning and ending of this, and indeed most construction projects. The temporality of the frogs worked differently: it was orientated around the seasonality of their habitat and its interaction with their own agencies, especially their capacity to breed. For these actors time was organized into temporal cycles: winter hibernation; breeding in early spring; spawning in ponds in late spring by females; tadpole metamorphosis into froglets over summer and early autumn; and then winter hibernation. The discovery of these actors started to disorganize the linear temporality of the project, as development around the waterhole was rescheduled: the project plan was delayed and now somehow had to take into account the cyclical time of the frogs; this dismayed the project managers in DEF. DEF's managers attempted to 'deal with' this disturbance to their organization of project time through practices of exclusion, but these exclusionary practices differed somewhat from those effected by Gasgen.

\section{Exclusion}

An apparent attempt to exclude the frogs from organizational space and time was reported in

a local newspaper in the autumn 2004 when the police were contacted by an 
environmentalist. When the police arrived they found several excavators digging near the ponds at the construction site and so brought work to a halt. After the incident, environmentalists claimed that DEF had deliberately tried to exterminate the frogs. The allegedly planned exclusion was quite unlike the sensitive negotiations with animal agencies practiced by Gasgen. Rather, it seemed to speak more to aspects of a managerialist control of 'Nature'. The cyclical time of the frogs was perceived as monstrous, an 'Other' to the linear time of project management. From the perspective of DEF's project management, the temporal monstrosity of the frogs corresponded not just to their disorganizing potential to threaten predetermined project deadlines, but also their lack of deadline. The frog's cyclical timing could not be represented in the linear, task end-date competition, temporality, of DEF's project management. By planning their extermination, the frogs were to be given a deadline, so they could become just another task on the critical path of DEF's project temporality.

But then this project management became unstuck. DEF's management claimed to the environmentalists and police that that they had already received permission to remove the waterholes. In other words, they sought to justify the extermination of the frogs on the basis of an earlier time in which the frogs were said to not exist. Evidence presented by the environmentalists - the frogs' spokespeople - suggested a clear link between the waterholes and frogs. Given the controversy, DEF considered gaining legal permission to relocate the frogs to a nearby waterhole beyond the spatial boundaries of the construction site. DEF eventually realized that an application to the authorities to move the frogs, which would no doubt require protracted, and costly, negotiations with the frogs and their spokespeople, might jeopardize the project's linear time schedule even if DEF were to get approval. 


\section{Invitation}

As a result of the delays, and the possibility of disorganization to the project schedule, DEF made a decision:

So, we ended up turning things around, saying 'ok', instead of fighting, they [the frogs] should be allowed to live there. But we must build anyway, so we need to know something about how this kind of frog would like to live. Then we followed suit and recruited the country's leading moor frog experts as our advisors (DEF project manager).

The frogs were now invited to make a difference to project management through their new spokespeople. This invitation disorganized and then reorganized the temporal boundaries of the project. Previously, time was predominantly perceived as linear and finite. The temporal boundaries were established with a stable beginning and an end and the activity in the project was supposed to progress according to a pre-established time plan, manifest on plans and charts. However, after the frogs were invited in new temporal concerns were introduced, changing the temporal organization of the project, as a DEF project manager explained in interview:

There is a particular time schedule for handling the frogs. When it is their breeding season, they want to use the pond. Then a frog fence will be erected to keep them on the trail. There is a frog fence where they exit the waterhole so they don't escape. 
Just as with the Gasgen project, the project was disorganized and reorganized once the frogs were invited into the space of project management: fences were erected to direct the behaviour of the frogs and make sure they were protected from the construction site machines and special frog corridors were built under the road so that frogs could wander relatively freely into and out of their habitat. But during the breeding season, between March and June, some barriers were opened and construction work near the waterhole was redirected and slowed to allow the frogs' unrestricted access to the water for breeding. As the above quote shows, DEF's time plan had to be supplemented by a different time plan that took the breeding cycle of the frogs into account. The different spatial, temporal and agential limits of project management and frog organization were not primarily just negotiated through reorganizing space as with our Gasgen case. In the DEF case, temporal boundaries came to the fore. The project was timed, as well as spaced, differently, because of its entanglements with animals, allowing different ways of organizing time not just to co-exist but also to influence each other. Rather than being excluded by linear project time, as initially appeared to be likely, the cyclical timing of the frogs was allowed to make a difference to the timing of the project, resulting in a slower, but hopefully more viable, project. Equally the timing of the frogs to breed was now at least partly dependent upon their compliance on their timed arrival and departure for breeding within a pre-determined plan within the linear charts of project management.

\section{Concluding discussion}


Our two empirical cases illustrate the diversity and complexity of human and animal boundary work. The construction industry was mobilized here to empirically develop new insights into how animals and humans organize different spaces and times through their entangled relations. Given the pervasive role of the built environment in effecting separations between animals and humans (Philo and Wilbert, 2000), we contend construction management is an important, and often overlooked (Sage, 2013), field through which such geographies are relationally constituted. Just as with other practices such as agricultural domestication, (construction project) management organizing, can thus shed light on the composite 'patchwork' of relational practices through which 'culture is divided from nature' (Lien and Law, 2011: 82). Even within the most managerial organizings such as a construction project, animal agencies, spacings and timings, make a difference to such separations. Our empirical examples thus challenge both managerialist (Santos and Eisenhardt, 2005) and poststructuralist (Bloomfield and Vurdubakis, 1999; Cooper, 1986) notions that animals are passive, or monstrously 'Other', to the boundary making that delineates the orderliness of (human) organization. Rather they are part of those ordering processes.

We proposed three concepts - Invitation, Exclusion and Disturbance - as heuristics to account for the relational boundary work that occurs between human/animal organizing. Each concept helped explain a distinctive process wherein human/animal agencies become constitutively entangled with another. 'Invitation' refers to the capacity of human animal agencies to interact and foster a collective, somewhat mutually dependant, fate for their different organizings. For example, the invitation of moor frogs, and their cyclical time, into the DEF project, served to allow the linear time of the project to continue, whilst also protecting the cyclical timing of the moor frogs. 'Disturbance' explains how unruly agencies, 
may circulate and delimit the spacing or timing of another agency without warning. Temporally, this can bring a halt to project management (as with the DEF example); and spatially, 'Disturbance' can, quite a-symmetrically, set new boundaries for one way of organizing. Finally, we also considered 'Exclusion', or separation, which is perhaps the most commonly acknowledged boundary practice between humans and animals. Spatially, as in the Gasgen case, 'Exclusion' concerns the boundary work that keeps human and animal ways of organizing, relatively, separate from each other, preventing mutual disorganization. Temporally, 'Exclusion' indicates boundary work where the timings of one way of organizing are forcibly excluded by the imposition of another. In the DEF case this resulted in the frogs being almost subject to annihilation, as for them, timing was a matter of life and death, not simply cost efficiency.

Our argument highlights the processes of adjudication between agential, spatial and temporal boundary work. For humans to organize, that is, become concerned with working up agential, spatial and temporal limits (Latour, 2013), this can involve complex entanglements with unruly animals, as well as technological agencies. We considered how human and animal organizing becomes entangled, so that a housing constructor times their working rhythms around the breeding patterns of frogs in order to build on schedule, or the survival of the habitats of a group of skylarks near a building site depends upon the extension of an ecological network that circulates the specification for vibrating bird scarring tape. Thus animal organizing is not simply a negated 'Other' (Bloomfield and Vurdubakis, 1999; Cooper, 1986), beyond human organizing but rather a constituent part of that organizing. Finally, and perhaps most significantly, our analysis challenges the association of management (Cederström and Fleming, 2012; Fleming and Spicer, 2004; Quattrone and Hooper, 2005, Parker, 2014, Winiecki, 2009), and especially project management (Law, 
2002b; Lundin and Söderholm, 1994), with the effacement of unruly, or 'wild', agencies, spacings and timings. The entanglements of animal/human organizings we encountered suggest that management does not simply involve the effacement of 'wild' animal agencies, spacings, timings in a humanistic, totalitarian, quest over 'Nature' (Klikauer, 2013; Newton, 2009; Parker, 2002). Management, and its mission to order space-time (Kornberger and Clegg, 2004; Quattrone and Hooper, 2005), even to control the boundaries of organization (Santos and Eisenhardt, 2005), may instead sometimes be partly enacted through, rather than against, different, even disorganizing, certainly troublesome, but never monstrous or simply managed, animal agencies.

\section{References}

Anderson, K. (2014) Mind over matter? On decentering the human in Human Geography, Cultural Geographies, 21(1): 3-18.

Bear, C. and Eden, S. (2008) Making space for fish: the regional, network and fluid spaces of fisheries certification, Social \& Cultural Geography, 9(5): 487-504.

Bear, C. and Eden, S. (2011) Thinking like a fish? Engaging with nonhuman difference through recreational angling, Environment and Planning D: Society and Space, 29(2): 336352. 
Bloomfield, P. and Vurdubakis, T. (1999) The Outer Limits: Monsters, Actor-Networks and the Writing of Displacement, Organization, 6(4): 625-647.

Callon, M. (1986) Some elements of a sociology of translation: domestication of the scallops and fishermen of St. Brieuc Bay”, in Law J. (ed.), Power, Action and Belief: a New Sociology of Knowledge? Routledge, London, 196-233.

Cederström, C. and Fleming, P (2012) Dead Man Working, Winchester: Zero Books.

Clegg, S. Kornberger, M. and Rhodes, C. (2005) Learning/Becoming/Organizing, Organization, 12(2): 147-167.

Clegg, S. Kornberger, M. Carter, C. and Rhodes, C. (2006) For Management? Management Learning, 37(1): 7-27.

Collins, H. and Yearly, S. (1992) Epistemological Chicken, in A. Pickering (ed), Science as Practice and Culture. Chicago: University of Chicago Press, 301-26.

Cooper, R. (1986) Organization/Disorganization, Social Science Information, 25(2): 299-355.

Deleuze, G. and Guattari, F. (1987) A thousand plateaus: capitalism and schizophrenia, Continuum: London.

Fleming, P. and Spicer, A. (2004) 'You can checkout anytime, but you can never leave’: Spatial boundaries in a high commitment organizations, Human Relations, 57(1): 75-94. 
Ginn, F. (2014) Sticky Lives: slugs, detachment and more-than-human ethics in the garden, Transactions of the Institute of British Geographers, 39(4): 532-544.

Grazian, D. (2012) Where The Wild Things Aren't: Exhibiting Nature in American Zoos, The Sociological Quarterly, 53(4): 546-65.

Greenhough, B. and Roe, E. (2011) Ethics, space, and somatic sensibilities: comparing relationships between scientific researchers and their human and animal experimental subjects, Environment and Planning D: Society and Space, 29(1): 47-66.

Hassard, J. Keleman, M. and Cox, J. (2008) Disorganization Theory: Explorations in Alternative Organizational Analysis, London: Routledge.

Holloway, L. (2007) Subjecting cows to robots: farming technologies and the making of animal subjects, Environment and Planning D: Society and Space, 25(6): 1041- 1060.

Jones, G., McLean, C and Quattrone, P. (2004) Spacing and timing, Organization, 11(6): 723-741.

Keul, A. (2013) Embodied encounters between humans and gators, Social \& Cultural Geography, 14(8): 930-53.

Klikauer, T. (2013) Managerialism: a Critique of an Ideology, London: Palgrave. 
Knox, H., O’Doherty, D. Vurdubakis, T. and Westrup, C. (2015) Something happened: Spectres of organization/disorganization at the airport, Human Relations, 68(6): 1001-1020.

Kornberger, M. and Clegg, S. (2004) Bringing Space Back In: Organizing the Generative Building, Organization Studies, 25(7): 1095-1114.

Latour, B (1986) Science in Action: How to Follow Scientists and Engineers Through Society, Harvard University Press, Cambridge, Mass.

Latour, B. (2004) The Politics of Nature, Cambridge, Mass: Harvard University Press.

Latour, B. (2005) Reassembling the Social, Oxford: Oxford University Press.

Latour, B. (2013) An Inquiry into Modes of Existence, Cambridge, Mass: Harvard University Press.

Law, J. (2002a) Objects and Spaces, Theory, Culture \& Society, 19(5/6): 91-105.

Law, J. (2002b) Aircraft Stories: Decentring the Object in Technoscience, Duke University Press: Durham, NC. 
Law, J. and Lien, E. (2013) Slippery: field notes in empirical ontology, Social Studies of Science, 43(3): 363-378.

Law, J. and Mol, A. (2008) The Actor-Enacted: Cumbrian Sheep in 2001, in C. Knappett and L. Malafouris L. (eds), Material Agency, New York: Springer Science and Business Media, 57-77.

Law, J. and Singleton, V. (2013) ANT and Politics: Working in and on the World, Qualitative Sociology, 36(4): 485-502.

Lien, M. and Law, J. (2011) 'Emergent Aliens': On Salmon, Nature, and Their Enactment, Ethnos: Journal of Anthropology, 76(1): 65-87.

Lorimer, J. (2008) Living Roofs and brownfield wildlife: towards a fluid biogeography of UK nature conservation, Environment and Planning A, 40(9): 2042-2060.

Lundin, R. and Söderholm, A. (1994) A Theory of Temporary Organization, Scandinavian Journal of Management, 11(4): 437-455.

Miele, M. (2011) The Taste of Happiness: Free-range chicken, Environment and Planning A, 43(9): 2076-2090. 
Milne, M. and Gray, R. (2013) W(h)ither Ecology? The Triple Bottom Line, the Global Reporting Initiative, and Corporate Sustainability Reporting, Journal of Business Ethics, 118(1): 13-29.

Mol, A. and Law, J. (2005) Boundary variations: an introduction, Environment and Planning D: Society and Space, 23(5): 637-42.

Murdoch, J. (1998) The Spaces of Actor-Network Theory, Geoforum, 29(4): 357-374.

Newton, T. (2009) Organizations and the Natural Environment, in M. Alvesson, T, Bridgman and H. Wilmott (eds.) The Oxford Handbook of Critical Management Studies, Oxford: Oxford University Press, 125-143.

November, V., Camacho-Hübner, E. and Latour, B. (2010) Entering a risky territory: space in the age of digital navigation, Environment and Planning D: Society and Space, 28(8): 581599.

Parker, M. (2002) Against Management, Polity Press: Cambridge.

Parker, M. (2014) University, Ltd: Changing a business school, Organization, 21(2): 281-92. 
Philo, C. and Wilbert, C. (2000) Animal space, beastly places: an introduction, in C, Philo and C, Wilbert (eds.) animal space, beastly places: new geographies of human-animal relations, London: Routledge, 1-34.

Quattrone, P. and Hopper, T. (2005) A ‘time’ space odyssey: Management control systems in two multinational organisations, Accounting, Organizations and Society, 30(7-8): 735-764.

Riach, K. and Kelly, S. (2015) The need for fresh blood: understanding organizational age equality through a vampiric lens, Organization, 22(3): 287-305.

Sage, D. (2013) ‘Danger building site-keep out!?’: a critical agenda for geographical engagement with contemporary construction industries, Social \& Cultural Geography, 14(2): 168-191.

Sage, D., Dainty, A., Tryggestad, K., Justesen, L. and Mouritsen, J. (2014) Building with wildlife: project geographies and cosmopolitics in infrastructure construction, Construction Management and Economics, 32(7-8): 773-786.

Santos, F. M. and Eisenhardt, K. M. (2005) Organizational boundaries and theories of organization, Organization science, 16(5): 491-508.

Schreyögg, G. and Sydow, J. (2010) CROSSROADS—Organizing for Fluidity? Dilemmas of New Organizational Forms, Organization Science, 21(6): 1251-1262. 
Tajima, K. (2003) New Estimates of the Demand for Urban Green Space: Implications for Valuing the Environmental Benefits of Boston’s Big Dig Project, Journal Of Urban Affairs, 25(5): 641-655.

Thanem, T. (2006) Living on the edge: Towards a monstrous organization theory, Organization 13(2): 163-93.

Tryggestad, K., Justesen, L. and Mouritsen, J. (2013) Project temporalities: how frogs can become stakeholders, International Journal of Managing Projects in Business, 6(1): 69-87.

Winiecki, D. (2009) The Call Centre and its Many Players, Organization, 16(5): 705-731.

Whittle, A. and Spicer, A. (2008) Is actor-network theory critique?, Organization Studies, 29(4): 611-29. 